\title{
Establishment and maintenance of regulating ecosystem services in a dryland area of central Asia, illustrated using the Kökyar Protection Forest, Aksu, NW China, as an example
}

\author{
S. Missall ${ }^{1}$, M. Welp ${ }^{1}$, N. Thevs ${ }^{2}$, A. Abliz ${ }^{1,3,4}$, and Ü. Halik ${ }^{3,4}$ \\ ${ }^{1}$ Faculty of Forest and Environment, Eberswalde University for Sustainable Development, \\ Eberswalde, Germany \\ ${ }^{2}$ Institute of Botany and Landscape Ecology, University of Greifswald, Greifswald, Germany \\ ${ }^{3}$ Key Laboratory of Oasis Ecology, College of Resources and Environmental Sciences, Xinjiang University, \\ Urumqi, China \\ ${ }^{4}$ Faculty of Mathematics and Geography, Catholic University of Eichstätt-Ingolstadt, Eichstätt, Germany \\ Correspondence to: S. Missall (siegmund.missall@posteo.de)
}

Received: 01 September 2014 - Published in Earth Syst. Dynam. Discuss.: 08 December 2014

Revised: 11 March 2015 - Accepted: 08 April 2015 - Published: 22 June 2015

\begin{abstract}
The city of Aksu, situated at the northern fringe of the Taklimakan Desert in northwest China, is exposed to severe periodic dust and sand storms. In 1986, local authorities decided to establish a peri-urban shelterbelt plantation, the so-called Kökyar Protection Forest, with the aim of reducing dust and sand storm impacts on Aksu City by the regulating ecosystem services provided by the plantation. It was realised as a patchwork of poplar shelterbelts and orchards. The total area of the plantation reached 3800 ha in 2005 . The Kökyar Protection Forest is used as a case study to answer the following question: under which institutional frameworks and to which financial conditions can peri-urban shelterbelts be established and maintained? The endeavour of planting the shelterbelt was made possible by the annual mass mobilisation of Aksu citizens, based on the Chinese regulation of the "National Compulsory Afforestation Campaigns". Establishment costs amounted to ca. CNY $60000 \mathrm{ha}^{-1}$ (ca. USD $10000 \mathrm{ha}^{-1}$ ). Permanent maintenance of the plantation is facilitated by leasing orchard plots to private fruit farmers. From the perspective of the local economy, annual farming net benefits generated by Kökyar fruit farmers more than compensate for annual government grants for maintenance, resulting in an average overall monetary net benefit of at least CNY $10500 \mathrm{ha}^{-1}$ (ca. USD $1600 \mathrm{ha}^{-1}$ ) in the long term. For a more complete understanding of Kökyar Protection Forest, future research should be directed towards quantifying the effect of its regulating ecosystem services and on investigating the negative downstream consequences of its water consumption.
\end{abstract}

\section{Introduction}

\subsection{Shelterbelts in China}

More than $40 \%$ of China's total territory is characterised by arid and semi-arid climates. These drylands are predominantly located in the north and especially in the northwest of the country ( $\mathrm{Li}$ et al., 2012). Shelterbelts have been seen as an effective instrument to fight negative influences of deserts and semi-deserts ever since the beginning of the People's Republic of China (Chokkalingam et al., 2006). The objectives of shelterbelts usually comprise environmental security (alleviating soil erosion, droughts, dust and sand storms, dry hot winds, etc.) and economic development (increasing crop production, stockbreeding production, timber production and other forest products, etc.). Structures and species composi- 


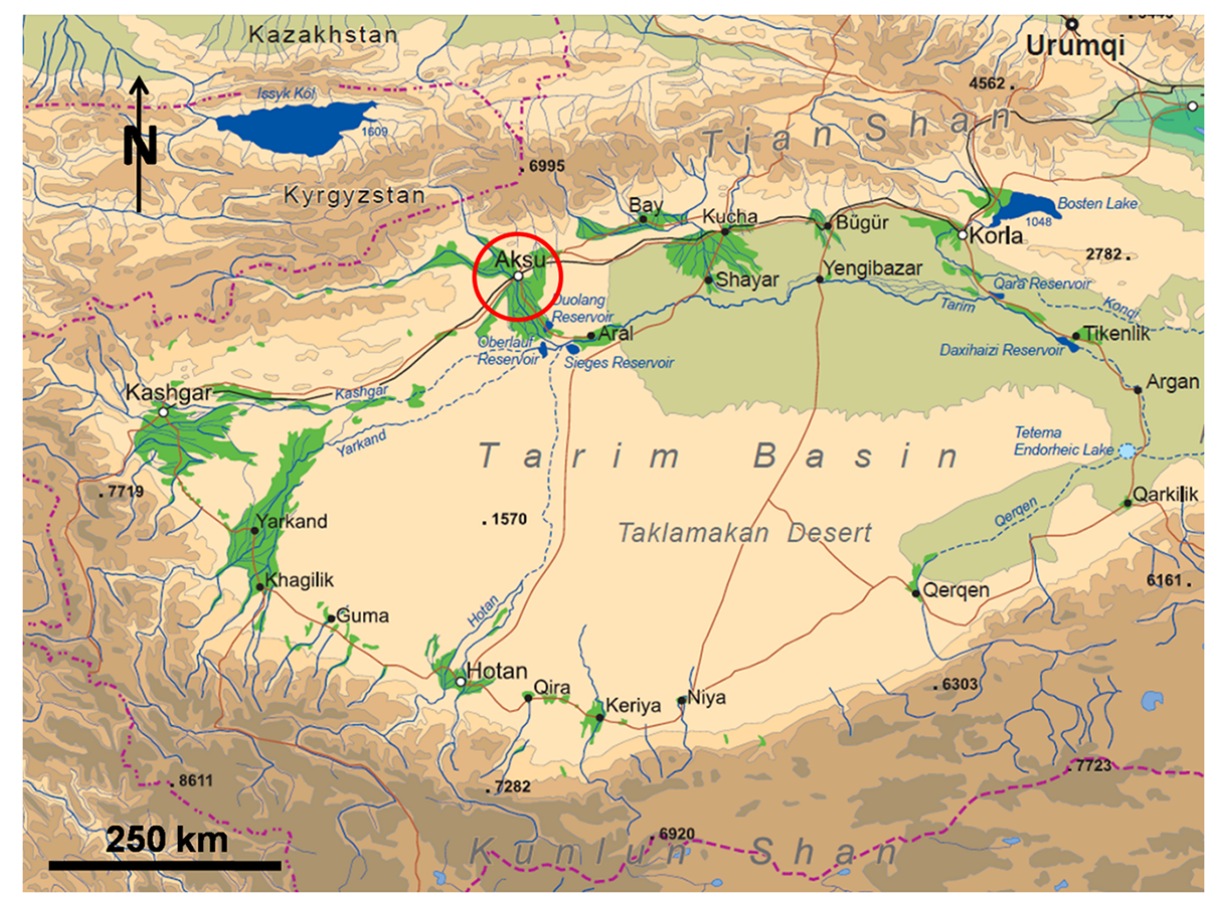

Figure 1. Geographic position of Aksu City in the Tarim Basin, northwest China (adapted from Paproth and Pietsch, 2011).

tions of the plantations alter according to site-specific conditions and purposes (Li et al., 2012; Chokkalingam et al., 2006). The biggest and globally best-known shelterbelt, the so-called Three-North Shelterbelt, is an overarching project that aims at increasing forest cover from 5 to $15 \%$ in an area of $4069000 \mathrm{~km}^{2}$ that stretches over 13 province-level administrative units from the northwest to the northeast. Its establishment began in 1987 and is expected to last until 2050. $244690 \mathrm{~km}^{2}$ have been afforested so far (Li et al., 2012).

A special shelterbelt type has developed in the Tarim Basin in northwest China. The Tarim Basin is framed by the Tian Shan in the north and the Kunlun and Karakorum Mountains in the south and southwest, with the Taklimakan Desert in between. The continental position, precipitation shadow of the mountain ranges, and intense solar radiation form a hyperarid climate. Oasis cities are located along the periphery of Taklimakan Desert, wherever rivers, running down from the surrounding mountains, provide sufficient water (cf. Fig. 1). Most of these cities, such as Korla, Bügür, Aksu, Kashgar or Hotan, have experienced rapid growth over the last decades, in the course of which natural greenbelts formed by native tree and shrub species have been eliminated by urban sprawl and agriculture. In order to protect the citizens from the influences of the surrounding desert lands, authorities of all these cities have tried to establish a special type of shelterbelt which could be labelled peri-urban protection forest: broad greenbelts that ideally should surround the cities from all sides (Halik, 2003). The Kökyar Protection Forest in Aksu was one of the first of these.

\subsection{Geographic conditions of Aksu City}

Aksu is a city of about 580000 inhabitants of which 314500 live in the urban core (Akesu Shi Renmin Zhengfu, 2012). It is the capital of Aksu Prefecture, lying in the west of China's northwestern Xinjiang Uyghur Autonomous Region, close to the border of Kyrgyzstan. At a geographical position of $41^{\circ} 10^{\prime} \mathrm{N}$ and $80^{\circ} 15^{\prime} \mathrm{E}$ and at an altitude of $1100 \mathrm{~m}$ a.s.l. (above sea level), it is situated on a long, slightly inclined slope between the Tian Shan in the north and the Taklimakan Desert in the south (cf. Fig. 1). The slope is traversed from northwest to southeast by the Aksu River, which is fed by snow and glacier meltwater as well as rainfall from the nearby Tian Shan as described in Rumbaur et al. (2015). The Aksu River has formed a flat $10 \mathrm{~km}$ wide valley with a steep bank of about $20 \mathrm{~m}$ height at its northeastern shore. The core of Aksu City lies exactly under the bank within the river valley, while today's suburbs spread deeper into the valley and over the bank.

An annual evaporation rate of $1868 \mathrm{~mm}$ and annual precipitation of merely $75 \mathrm{~mm}$ indicate an extremely arid climate (Kökyar Annals Compilation Committee, 2006). Due to its location on the Aksu River, Aksu receives sufficient water to ensure agriculture, which means that the city is located in a huge river oasis (ca. $1000 \mathrm{~km}^{2}$, including Awat and Onsu County; Halik, 2003). However, the arid environment becomes very clear whenever the regular hot and dry north winds blow down from the Tian Shan (Föhn effect). Maximum wind speeds are reached in springtime $\left(15 \mathrm{~m} \mathrm{~s}^{-1}\right)$ (Yoshino, 1992). Raising dust and sand from the barren areas 
north of the oasis, the north winds cause an annual average of 11.5 sand storm days (visibility less than $1 \mathrm{~km}$ ) in Aksu City (Kökyar Annals Compilation Committee, 1996; also cf. Sect. 3.2, "Site conditions"). The severe dust and sand storms of Aksu blacken the sky, making respiration difficult, covering everything outside and inside houses with brown dust, inhibiting traffic, and disrupting public life (Aksu Prefectural Forestry Department and Kuqa Television Station, 2006; Aksu Prefectural Greening Committee, 2006; Aksu citizen interviews, 2011).

During the 1980s, the dust and sand storms were increasingly perceived as a major problem for the city. There are two probable factors for this change in perception. Firstly, in the previous decades, Aksu City had undergone fast socioeconomic changes: the composition of the population shifted from a nearly $100 \%$ autochthonous Uyghur society to a population the majority of which consisted of foreign HanChinese settlers, and the city was transforming from a small rural oasis town into a regional industrial and service centre (Halik, 2003; Intercontinental Pan-Chinese Network Information Co. Ltd., 2008). A different environmental and cultural background of the settlers and changing ideas of the living standards in cities may have fostered the new perception of the problem. Secondly, the immigration-based growth and the economic development of oasis cities in the Tarim Basin was usually accompanied by the degradation of the natural vegetation at the fringes of the oases, thus compromising their regulating ecosystem services and contributing to a factual aggravation of dust and sand problems (Halik, 2003). However, there is no literature on the specific situation around Aksu City.

\subsection{The Kökyar Protection Forest}

As a response to the dust problems, in the 1980s the local authorities decided to lay out a peri-urban shelterbelt plantation, called Kökyar Protection Forest. Work began in 1986 and was completed in 1990, the plantation then covering an area of 1308 ha (Kökyar Annals Compilation Committee, 1996). From 1990 onward, the project was extended by three more project periods, each of which converted more patches of desert land into forest plantations (cf. Fig. 2). The four project periods and their corresponding areas were then chronologically labelled Kökyar I to IV, while the complete title, Kökyar Protection Forest, usually refers to all four project areas together. According to local authorities, the total area covered 3842 ha by 2005 (Kökyar Annals Compilation Committee, 2006; Aksu Prefectural Greening Committee, 2006).

The Kökyar Protection Forest is not unique but rather forms part of a series of such greening projects in different cities of the Tarim Basin, e.g. in Korla, Kashgar and Hotan (Halik, 2003). However, among them all, Kökyar is regarded as a kind of lighthouse project due to its vast dimensions and because it was realised without the aid of the central govern-

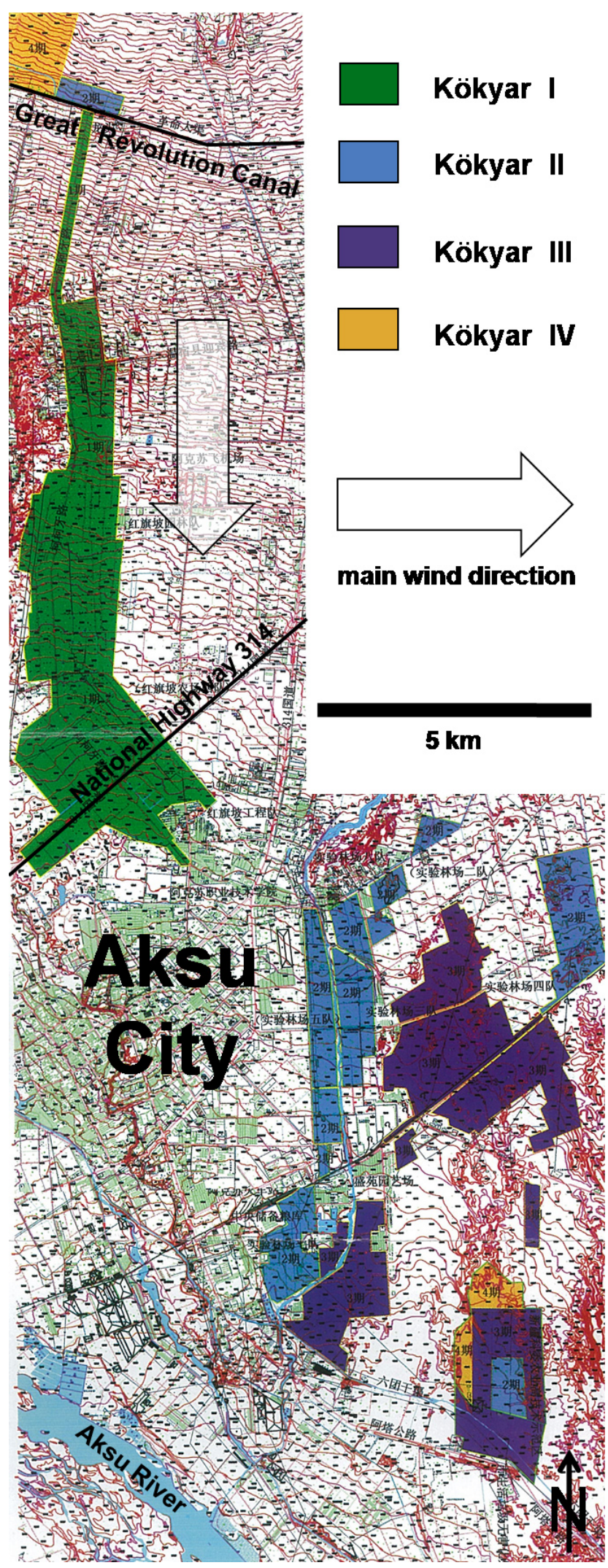

Figure 2. The project areas of Kökyar I, II, III and IV (partial view; adapted from Kökyar Annals Compilation Committee, 2006). 
ment. An accompanying publicity effort, including the publication of books and documentaries as well as the erection of a large exhibition hall, further boosted its prominence. In 1996, it was included in the "Global 500 Role of Honour for Environmental Achievement" of the United Nations Environmental Programme (Kökyar Annals Compilation Committee, 1996). It is a showcase project in China and could be a model for other drylands. This paper undertakes an exemplary analysis of the Kökyar Protection Forest, with the following research question in mind: under which institutional frameworks and which financial conditions can periurban shelterbelts be established and maintained? This analysis may turn out to be helpful for the planning or running of other similar projects, especially in geographically similar areas.

\section{Methods}

The data for this paper are drawn from existing literature on the Kökyar Protection Forest, a socio-economic household survey on Kökyar farmers conducted by the authors in 2012, and some additional interviews conducted by the authors in 2011 and 2012.

Literature on Kökyar is scarce and, to date, available exclusively in Chinese. The main sources of information on the project are, firstly, the "Annals of the Kökyar Greening Project" in two volumes, provided by the Kökyar Annals Compilation Committee, a committee constituted by the project managers; secondly, a coffee table book called "Green Kökyar" produced by the Aksu Prefectural Greening Committee; and thirdly: a documentary with the title of "The Green Feat: Commemorating 20 Years Construction of Kökyar" by the Aksu Prefectural Forestry Department and Kuqa Television Station. This paper draws heavily on the "Kökyar Annals", especially for the description of the establishment process of Kökyar, and, to a minor extent, on the other two sources. Since all these sources were written or produced under the aegis of persons and organisations involved in the establishment process of the Kökyar Protection Forest, there is a certain danger of bias in favour of the project.

The existing sources of information on Kökyar neglect to give any figures for the running costs of the project or the actual economic situation of the farmers within its area. To close this knowledge gap, a socio-economic household survey was conducted in 2012. A raster of 19 evenly distributed sample points was projected on the whole area of Kökyar I, and subsequently the closest available household to each ideal sample point was identified. All the sample households lie within a radius of $200 \mathrm{~m}$ from the ideal sample points. The heads of the 19 identified households were interviewed in Chinese (except for one that was interviewed in Uyghur) according to a fixed questionnaire (cf. Appendix A).

For information on the institutional processes and economic conditions of the state-owned organisations running the project, a semi-structured interview with the former head of the Forest Management Station was conducted. Other important information on the general circumstances surrounding the Kökyar Protection Forest was gathered by interviews with randomly selected Aksu citizens, a private farming consultant in Aksu, and a seasonal worker on the plantation. All these interviews were conducted between 2011 and 2012 (cf. Appendix A).

In order to make the costs of and income from Kökyar Protection Forest comparable between all different time periods between 1986 and today, monetary values will be presented adjusted for inflation, in their actual monetary value of the year 2014. The Chinese yuan, abbreviated as CNY, is traded at about USD 0.16.

The economic situation of the main actors in the Kökyar Protection Forest (i.e. private fruit farmers within the plantation and state-owned managing organisations) is estimated by cash-based accounting. The effect of the Kökyar Protection Forest on the local welfare is summarised through cost-benefit analysis. Cost-benefit analysis is an assessment method that "quantifies in monetary terms the value of all consequences of a policy to all members of society" (Boardman et al., 2011). In contrast to normal accounting practices applied by profit-oriented corporations to identify the most profitable investment opportunities, cost-benefit analysis is not limited to the monetary costs and benefits of the decision maker himself but accounts for all marketable and nonmarketable costs and benefits experienced by all individuals residing within the area of interest (Mishan and Quah, 2007). In a nutshell, a "benefit" is an increase in human wellbeing, and a "cost" is a reduction in human wellbeing (OECD, 2006). The term "net benefit" (i.e. subtraction of costs from benefits) therefore represents the overall societal welfare gain of a country or region. For the analysis conducted in this paper, the scope will be narrowed down to the local level, which means that downstream ecological costs caused by the Kökyar water consumption, although they undoubtedly exist, will not be included. The focus will be on marketable costs and benefits, while non-marketable effects will be qualitatively described (for more general information on cost-benefit analysis, cf. Boardman et al., 2011).

\section{The establishment of Kökyar Protection Forest}

\subsection{Emergence}

The first scheme of the later Kökyar Protection Forest was developed in 1985, when water was needed for planned roadside greening along National Highway 314, north of the urban core of Aksu. The Aksu Prefectural Party Committee decided to build a new canal branch from the existent northern Great Revolution Canal (geming daqu) leading southward to the planned greening site (cf. Fig. 2). The terrain to be crossed by the canal was the area of the later Kökyar Protection Forest. Because of its unfavourable environ- 
ment (cf. following section), it was decided to protect the canal with poplar shelterbelts on each side. A year later, in 1986, the original plan was enlarged to cover the whole area with a protection forest, and the title "Kökyar Greening Project" was suggested (Kökyar Annals Compilation Committee, 1996). "Kökyar" means "green cliff" in the Uyghur language.

\subsection{Site conditions}

The plantation site of the Kökyar Protection Forest lies in the north of Aksu City. It is a long stretch with an area of 1308 ha that extends $15.8 \mathrm{~km}$ from the Great Revolution Canal in the north to the suburbs of Aksu City in the south (cf. Fig. 2). It lies above Aksu City on an old fluvial terrace which slopes slightly from $1230 \mathrm{~m}$ a.s.l. in the north to $1125 \mathrm{~m}$ a.s.l. in the south. Most of its western boundary is defined by a steep bank of $20 \mathrm{~m}$ down to the Aksu River valley. The cut bank was canyoned by erosion gullies which extended deep into the area of later Kökyar, thus posing great problems for the levelling of the planting ground and the construction of canals (Kökyar Annals Compilation Committee, 1996).

The fluvial terrace itself is composed of brown desert soil lying upon a gravel bed. The grain size at the surface changes from sandy gravel in the north to sandy silt and clay in the south. A high groundwater table and the regional extreme evaporation rate result in an average soil salinity of $2.87 \%$ and $\mathrm{pH}$ values of 7.1 to 9.0 . Before the afforestation, the soil was predominantly devoid of vegetation, with some areas being sparsely covered by Alhagi sp. and other herbaceous plants. The barren soil of the Kökyar plateau was regarded as a major source of material during wind erosion, thus contributing to the regular northerly dust and sand storms in Aksu City (cf. Fig. 2; Kökyar Annals Compilation Committee, 1996; Aksu Prefectural Forestry Department and Kuqa Television Station, 2006).

\subsection{Design}

The plantation was established as a raster of shelterbelt strips consisting mainly of white poplar (Populus alba 'Pyramidalis') with fruit plantations in between. In the 5 years between 1986 and 1990, 686 ha of poplar shelterbelts and 623 ha of orchard were planted, totalling 1308 ha and 1085000 trees (Kökyar Annals Compilation Committee, 1996).

The infrastructure backbone of the plantation is formed by a vertical main canal and a parallel main asphalt road which link the Great Revolution Canal in the north with the city of Aksu in the south, providing the area with water and making it accessible. This main axis has a length of $15.8 \mathrm{~km}$ and is protected by a shelterbelt strip of $100 \mathrm{~m}$ width on each side. The areas east and west of it are criss-crossed by a regular grid of, in total, about $125 \mathrm{~km}$ of dirt roads and a hi-

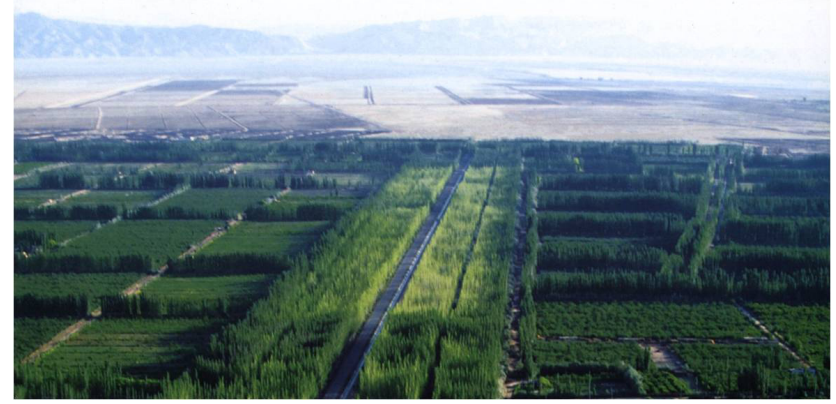

Figure 3. Aerial view of the northern edge of Kökyar I (adapted from Aksu Prefectural Greening Committee, 2006).

erarchical system of subordinate irrigation canals. Shelterbelts, planted in single or double rows, protect the dirt roads and subordinate canals, forming a chequered pattern over the area (cf. Fig. 3). The rectangular fields in between are filled with orchards (for details of the orchard management, cf. Sect. 4.3, "The perspective of the farmers"). Hundreds of small farm houses are distributed throughout the orchards. Furthermore, the area is equipped with all necessary technical infrastructure, such as water gates, waterlocks, overflows, bridges, drainage canals, water tabs, power lines, telephone lines and administrative buildings.

Today, the shelterbelts of Kökyar I consist mainly of white poplar (Populus alba 'Pyramidalis') in dense rows, partly mixed with Euphrates poplar (Populus euphratica), and some oleaster (Elaeagnus angustifolia), tamarisks (Tamarix) and willows (Salix) in the understorey. Most white poplars have reached breast diameters of $20-30 \mathrm{~cm}$, with some reaching up to $60 \mathrm{~cm}$ (field observations 2012).

The later project periods of Kökyar II, III and IV are not located in the direct vicinity of Kökyar I. They are spread over the most problematic dust fields to the north and east of Aksu City (cf. Fig. 2). Their layout follows the basic design of Kökyar I, but they tend to have smaller shelterbelt areas compared to total area (cf. Table 1; Aksu Prefectural Greening Committee, 2006). For the most recent scheduled project period, Kökyar IV, data have yet to be published.

\subsection{Key actors}

In 1986, the Prefectural Party Committee authorised two important governmental organisations, the Aksu River Drainage Area Management Department (akesu heliuyu guanlichu) and the Prefectural Forestry Department (diqu linyechu) to run the project jointly. Each of them founded an on-theground working station, especially for the purpose of establishing and managing the plantation: the Kökyar Greening Project Water Management Station (kekeya lühua gongcheng shui guanzhan; referred to as the Water Management Station hereafter) and the Kökyar Greening Project Protection Forest Management Station (kekeya lühua gongcheng fanghulin 
Table 1. Overview of the present four project periods of Kökyar Protection Forest. Bold numbers: sums of single project areas; italic numbers: provisional figures of the planned extent.

\begin{tabular}{lcrrrcc}
\hline $\begin{array}{l}\text { Kökyar } \\
\text { project } \\
\text { period }\end{array}$ & $\begin{array}{r}\text { Time } \\
\text { frame }\end{array}$ & $\begin{array}{r}\text { Total } \\
\text { area } \\
\text { [ha] }\end{array}$ & $\begin{array}{r}\text { Shelterbelt } \\
\text { area } \\
\text { [ha] }\end{array}$ & $\begin{array}{r}\text { Orchard } \\
\text { area } \\
{[\text { ha] }}\end{array}$ & $\begin{array}{r}\text { Shelterbelt } \\
\text { area } \\
{[\%]}\end{array}$ & $\begin{array}{r}\text { Orchard } \\
\text { area } \\
{[\%]}\end{array}$ \\
\hline Kökyar I & $1986-1990$ & 1308 & 686 & 623 & 52 & 48 \\
Kökyar II & $1991-1998$ & 1001 & 423 & 578 & 42 & 58 \\
Kökyar III & $1999-2005$ & 1533 & 153 & 1380 & 10 & 90 \\
Kökyar I-III & $\mathbf{1 9 8 6 - 2 0 0 5}$ & $\mathbf{3 8 4 2}$ & $\mathbf{1 2 6 2}$ & $\mathbf{2 5 8 0}$ & $\mathbf{3 3}$ & $\mathbf{6 7}$ \\
Kökyar IV & $2006-2010$ & 10000 & & & & \\
Kökyar I-IV & $\mathbf{1 9 9 6 - 2 0 1 0}$ & $\mathbf{1 3 8 4 2}$ & & & & \\
\hline
\end{tabular}

guanzhan; referred to as the Forest Management Station hereafter) with a staff of about 50 persons each (Kökyar Annals Compilation Committee, 1996; interview 1). The main task of the River Management Department and its local Water Management Station lay in preparing the planting ground through spatial planning, bulldozing the terrain, establishing a road network, building irrigation canals, and other hydraulic engineering for the provision of irrigation water and drainage canals to depress the saline ground water level (Kökyar Annals Compilation Committee, 1996; interview 1), while the main task of the Forestry Department and its local Forest Management Station lay in forest design planning, provision of cuttings and saplings and afforestation management (Kökyar Annals Compilation Committee, 1996).

Many other governmental organisations or governmentowned enterprises, e.g. the Prefectural Traffic Department, the Prefectural Road Construction Group, the state-owned Experimental Forest Site or the also state-owned Red Flag Slope Farm, contributed to the establishment of Kökyar Protection Forest with expertise, labour, resources or money; however, the main promoters were the River Management Department and the Forestry Department with their corresponding on-the-ground stations (Kökyar Annals Compilation Committee, 1996; interview 1). As there was a shortage of government funds, none of these institutions were given additional funding by the local government. Therefore, they had to restructure their regular annual budgets in order to mobilise funds for the project (Kökyar Annals Compilation Committee, 1996; interview 1).

Kökyar II (1991-1998) was organised and implemented by the same governmental institutions, and in the same manner, as Kökyar I.

For Kökyar III, in contrast, a market economy approach was chosen: the land was given to private entrepreneurs who were freed from rent payments and water fees for the first few of years but had to make all other necessary investments themselves. In return, they can keep all revenues generated on the land for themselves, according to the principle of "who invests earns" (Aksu Prefectural Greening Committee, 2006).

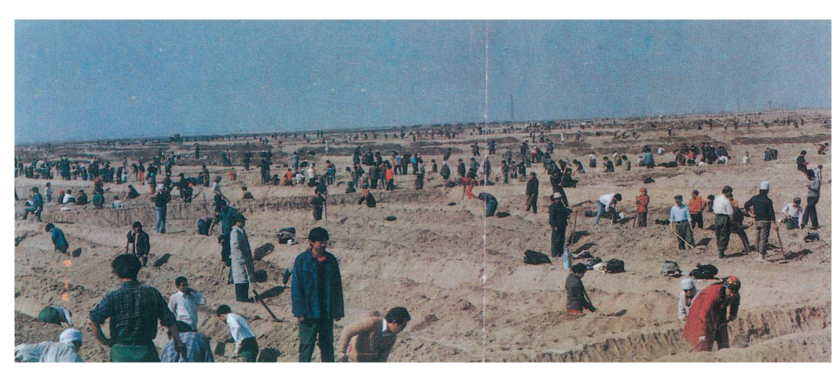

Figure 4. Compulsory labour on the Kökyar fields (adapted from Kökyar Annals Compilation Committee, 1996).

\subsection{Compulsory labour}

In order to meet the challenge of establishing huge forest areas in a poor financial situation, a legal regulation adopted in 1981 obliging all Chinese citizens to participate in "National Compulsory Afforestation Campaigns" (quanmin yiwu zhishu yundong) played a key role (Halik, 2003; interview 1). Based on this regulation, beginning from 1986 the Aksu Prefectural Party Committee called "all citizens, no matter which ethnicity, military or civilian" to participate in compulsory labour (yiwu laodong) on the fields, levelling the terrain, preparing the ground and planting trees through hard physical labour (Kökyar Annals Compilation Committee, 1996; interview 1). In reality, it seems that mainly prefectural governmental organisations and prefectural government-owned enterprises under the direct order of the Aksu Prefectural Party Committee were convinced or forced to take part, e.g. prefectural administration, police and prefectural schools (interview 1). Even so, the mobilisation of manpower reached very high levels: about 70 different organisations and enterprises sent thousands of workmen twice a year, for periods of 8,12 or even 30 days at a time (cf. Fig. 4). On one top day in 1988, 8459 people were working on the desert plateau simultaneously (Kökyar Annals Compilation Committee, 1996). Although the areas of Kökyar III were to be developed and exploited by private investors, the system of calling ordinary citizens to compulsory labour was maintained, thus significantly supporting newly 
evolving large landholders with gratis manpower (Aksu Prefectural Greening Committee, 2006).

\subsection{Initial investment costs}

The establishment costs of Kökyar I are more or less systematically listed in the Kökyar Annals (Kökyar Annals Compilation Committee, 1996), comprising the costs of bulldozing and other heavy earthworks, all types of water engineering, the construction of asphalt and dirt roads, telephone and power lines, and the costs of the afforestation itself, as they were borne by the major contributing organisations (cf. Table 2; Kökyar Annals Compilation Committee, 1996). However, some matters of expense are omitted by the Annals: firstly, the costs of surveying, planning, organising etc.; secondly, the costs of establishing drinking water facilities; and thirdly, the costs of compulsory labour. While we cannot, in retrospect, ascertain the costs of the first and second point, there is a way to approximate the costs of the third point, compulsory labour. The Kökyar Annals exactly list the physical extent of compulsory labour performed for the establishment of Kökyar Protection forest but fail to treat it as a matter of cost, probably because it appeared cost-free to the project makers. However, compulsory labour did, of course, involve costs, but the costs were passed along as opportunity costs to those institutions, organisations and enterprises which had to provide the workers and to the workers themselves, who had to pay for shovels and picks as well as for transportation (interview 1). The opportunity cost of 1 manday can be calculated by the fee of CNY 30 people had to pay if they were unable to attend compulsory labour (interview 1; value not adjusted for inflation). Multiplying the value of this fee by 346000 performed man-days, and further adding tool and transportation costs, reveals that compulsory labour, in fact, was the largest single expense of Kökyar I (interview 1; Kökyar Annals Compilation Committee, 1996). Adjusted for inflation and calculated per area, the overall establishment costs of Kökyar I amount to CNY $61245 \mathrm{ha}^{-1}$ or, if compulsory labour is excluded from the calculation, CNY $38700 \mathrm{ha}^{-1}$ (cf. Table 2).

The validity of this cost calculation for Kökyar I, as it is given in the Kökyar Annals, can be cross-checked by comparison with the costs given for Kökyar III in another publication: a 2006 publication with the title "Green Kökyar" indicates the establishment costs of Kökyar III based on the examples of one single investor commanding over 333 ha and a group of 13 investors commanding over 1200 ha (Aksu Prefectural Greening Committee, 2006). Adjusting their costs for inflation and calculating them per area allows a comparison between the establishment costs of Kökyar I and Kökyar III (cf. Table 3).

The comparison shows that installation costs of both project periods are, roughly speaking, of the same magnitude. The coherence between these numbers can be taken as evidence that the cost calculation of Kökyar I is realistic and that the costs of the past are transferrable to the present.

\section{The present functioning of the Kökyar Protection Forest}

\subsection{The leasing system}

In 1981, the State Council of the PR China had started promoting private forestry on a leasing basis by its "Resolution on Issues Concerning Forest Protection and Development" (guanyu baohu senlin, fazhan linye ruogan wenti de jueding; for background, cf. Delang and Yuan, 2015). In 1987, when the Kökyar afforestation work was still in the early stages, the Forest Management Station and Water Management Station reacted to this resolution and to the dire financial situation of their afforestation project with the introduction of a leasing system that is fundamentally still in force today: plots of already planted orchards, and plots which were ready for planting were leased to private fruit farmers (Kökyar Annals Compilation Committee, 1996). Leasing contracts guarantee them, for a period of about 10 to 15 years, a small section of orchard land (mostly between 0.5 and 1 ha, which may include single- or double-row poplar shelterbelts on one or two sides of the plots), a regular irrigation water supply and some technical advice on fruit production (Kökyar socio-economic household survey). (Socio-economic household survey, 2012). The leasers, in return, have to pay a substantial lease and an irrigation water fee. Additionally, they have certain duties and prohibitions. The main duty is to annually attend 7 to 50 days of compulsory labour, which is mostly maintenance work on the shelterbelt plantations and the irrigation canals. The main prohibition is not to damage the poplar plantations by cutting trees or branches (even if they overshadow fruit trees) or by grazing. The leasers have to compensate for any loss of poplar trees on their area. Some contracts further contain prohibitions to change the cultivation from fruit trees to field crops, although cultivating fruit trees is the most promising economically anyway (Kökyar socio-economic household survey).

This system of economic incentives and regulative norms, as it is fixed in the lease contracts, guarantees the cultivation and persistence of vigorous orchards amongst undamaged poplar shelterbelts, it provides free labour for the maintenance of infrastructure and poplar shelterbelts, and it ensures an income for the lessor organisations that they can reinvest into the plantation. The project leaders soon recognised the leasing system as an instrument to successively transform Kökyar from a purely government-sponsored protection forest into a self-supporting protection forest (Aksu Prefectural Greening Committee, 2006). Consequently, they tried to set the lease as high as possible, without the leasers backing out (interview 1; Kökyar socio-economic household survey).

Kökyar II is organised in the same way as Kökyar I. 
Table 2. The establishment costs of Kökyar I.

\begin{tabular}{|c|c|c|c|c|}
\hline Cost item & $\begin{array}{r}\text { Initial } \\
\text { investment } \\
\text { costs } \\
\text { (million } \mathrm{CNY} \text { ) }\end{array}$ & $\begin{array}{r}\text { Adjusted for } \\
\text { inflation }(2014) \\
(\text { million CNY) }\end{array}$ & $\begin{array}{r}\text { Calculated } \\
\text { per area* } \\
\left(\mathrm{CNY} \mathrm{ha}^{-1}\right)\end{array}$ & $\begin{array}{r}\text { Share } \\
\text { of total } \\
(\%)\end{array}$ \\
\hline $\begin{array}{l}\text { Management (surveying, } \\
\text { planning, organising, etc.) }\end{array}$ & (unknown) & (unknown) & (unknown) & \\
\hline $\begin{array}{l}\text { Bulldozing (and other heavy } \\
\text { earthworks) }\end{array}$ & 2.351 & 7.989 & 5745 & 9 \\
\hline $\begin{array}{l}\text { Water engineering (including } \\
\text { all tasks of the River } \\
\text { Management Department) }\end{array}$ & 7.538 & 21.516 & 15480 & 25 \\
\hline $\begin{array}{l}\text { Road construction (asphalt } \\
\text { and dirt roads) }\end{array}$ & 4.387 & 12.523 & 9015 & 15 \\
\hline Drinking water facilities & (unknown) & (unknown) & (unknown) & \\
\hline $\begin{array}{l}\text { Cable system (power lines and } \\
\text { telephone lines) }\end{array}$ & 0.807 & 2.302 & 1650 & 3 \\
\hline $\begin{array}{l}\text { Afforestation (including all } \\
\text { tasks of the Prefectural } \\
\text { Forestry Department) }\end{array}$ & 2.800 & 9.441 & 6795 & 11 \\
\hline Compulsory labour & 11.347 & 31.324 & 22545 & 37 \\
\hline TOTAL & 29.463 & 85.095 & 61245 & 100 \\
\hline
\end{tabular}

Table 3. Comparison of initial investment costs between Kökyar I and parts of Kökyar III, excluding costs of compulsory labour.

\begin{tabular}{lrcrc}
\hline $\begin{array}{l}\text { Area } \\
\text { denomination }\end{array}$ & $\begin{array}{r}\text { Initial } \\
\text { investment } \\
\text { costs } \\
\text { (million CNY) }\end{array}$ & $\begin{array}{r}\text { Adjusted for } \\
\text { inflation (2014) } \\
\text { (million CNY) }\end{array}$ & $\begin{array}{r}\text { Area } \\
\text { size } \\
(\text { ha) }\end{array}$ & $\begin{array}{c}\text { Initial } \\
\text { investment } \\
\text { costs } \\
\left(\mathrm{CNY} \mathrm{ha}^{-1}\right)\end{array}$ \\
\hline Kökyar I & 18.116 & 53.771 & 1389 & 38700 \\
\hline $\begin{array}{l}\text { Zhang Lianzhi } \\
\text { (part of Kökyar III) }\end{array}$ & 7.000 & 10.006 & 333 & 30015 \\
\hline $\begin{array}{l}\text { 13 investors } \\
\text { (part of Kökyar III) }\end{array}$ & 30.000 & 42.734 & 1200 & 35205 \\
\hline
\end{tabular}

Kökyar III also features an orchard leasing system, with the main difference being that the local government withdraws and private large-scale investors step into the role of the governmental lessor organisations: they act as the main tenants, who first make the necessary infrastructure investments and then sublease their large estates as small plots to hundreds of leasing households, compensating for their initial investment costs with income from the subleases (for examples of area sizes of main tenants, see Table 3 ). The exact conditions under which the main tenants obtain land from the government have not been researched. However, it seems that the privatisation of the protection forest business has advanced the idea of converting Kökyar into a self-supporting system, as government grants have been reduced substantially ever since (Aksu Prefectural Forestry Department and Kuqa Television Station, 2006).

\subsection{The perspective of Aksu citizens}

Shelterbelts in drylands are generally assumed to provide vital regulating ecosystem services, such as air humidification and cooling, wind speed reduction, air filtration, and soil fixation (Yimit et al., 2006; Halik, 2003; Chokkalingam et al., 
2006). Among these, air filtration and soil fixation are of the greatest relevance for Aksu City, since these ecosystem services have the effect of dust and sand storm mitigation, the primary reason for which Kökyar Protection Forest was initiated. An improvement of the dust and sand storm situation of Aksu City after the establishment of Kökyar Protection Forest is claimed by the Kökyar Annals (Kökyar Annals Compilation Committee, 1996; for details cf. next paragraph) and has been perceived and described by Kökyar farmers (Kökyar socio-economic household survey) and Aksu citizens (Aksu citizen(s) interviews, 2011; also cf. Halik, 2003). However, the precise contribution of Kökyar to this positive development is hard to determine, since there are other contributing factors in addition to Kökyar, such as the extension of the irrigated agricultural area around Aksu, the protection of the natural vegetation in the surrounding deserts and semideserts through a programme which reduces livestock densities, and fluctuations in precipitation patterns (interview 2; Yimit et al., 2006; Yang and Cui, 2006).

The first volume of the Kökyar Annals illustrates the Kökyar effect by presenting figures for reduced "windborne sand events" (fengshaci) in three periods between 1954 and 1990 (cf. Table 4; Kökyar Annals Compilation Committee, 1996). The figures demonstrate, first of all, that the situation in Aksu City and Onsu County Town, which are directly adjacent to Kökyar Protection Forest, improved considerably over this period, whilst at the Fifth Corps of the First Agricultural Brigade, which is $60 \mathrm{~km}$ away from Kökyar (Kökyar Annals Compilation Committee, 1996), windborne sand events remained frequent, thus indicating that local measures have caused this improvement. Furthermore, the table demonstrates that the situation at Aksu and Onsu was relatively stable between the first two periods but suddenly grew significantly better in the third period, thus indicating that a new measure starting from 1987 must have caused the improvement. Spatial and temporal coincidences combine to provide strong evidence for Kökyar being the main factor effecting the reduction of sand storm events.

This data set, however, does not clarify the physical properties of the alleged reduction, whereby the term "windborne sand events" obscures the duration of each "event" as well as the concentration of airborne particles. The second volume of the Kökyar Annals does present dust quantities by annual averaged densities of "total suspended particles" (TSP), but only for the years from 1996 till 2006, thus not allowing a comparison with the previous years (Kökyar Annals Compilation Committee, 2006). For the clarification of the exact dust and sand storm mitigation effect of Kökyar Protection Forest, more research is necessary.

Methods for the economic valuation of ecosystem services could theoretically attach annual monetary values to dust and sand storm mitigation effects. The Kökyar Annals indeed present a precise figure for the Kökyar Protection Forest, attaching a value of CNY $285 \mathrm{ha}^{-1}$ to the joint effect of airborne sand reduction and soil fixation (Kökyar Annals Com-
Table 4. Annual windborne sand events in the region of Aksu City 1954 to 1990 .

\begin{tabular}{rrcc}
\hline Time frame & $\begin{array}{r}\text { Aksu } \\
\text { City }\end{array}$ & $\begin{array}{c}\text { Onsu } \\
\text { County } \\
\text { Town }\end{array}$ & $\begin{array}{c}\text { Fifth } \\
\text { corps }\end{array}$ \\
\hline $1954-1980$ & 11.9 & 5.6 & 16.5 \\
$1981-1986$ & 10.8 & 5.3 & 22.2 \\
$1987-1990$ & 4.3 & 1.0 & 20.5 \\
\hline
\end{tabular}

pilation Committee, 1996; value adjusted for inflation). However, this figure is cited from a publication which is not focused on peri-urban protection forests in drylands but rather aims at estimating the average value of a Chinese forest (Qi, 2007; Lang and Li, 2000). Since Kökyar Protection Forest is established precisely on the largest dust fields in the region where it has the maximal impact on a large urban population in the immediate vicinity, it is expected to have a far above average value, and the presented figure is likely to understate the true monetary value of Kökyar's regulating ecosystem services.

Because of uncertainties in respect to the physical properties as well as the monetary value of the dust and sand storm mitigation effect exerted by the Kökyar Protection Forest, this paper refrains from expressing the benefits of its regulating ecosystem services in monetary terms. Yet, the principal fact that Kökyar reduces dust and sand storms appears to be beyond doubt.

\subsection{The perspective of the farmers}

The following description of the socio-economic situation of the Kökyar farmers is based on a household survey conducted in 2012 in the area of Kökyar I. The transferability of the survey to Kökyar II and III is uncertain. Their leasing conditions may differ, while the market and environmental conditions are very similar.

The Kökyar I leasers are recruited mostly from the huge pool of Han-Chinese migrant workers, who jumped at the chance to get settled there with their families (Kökyar Annals Compilation Committee, 1996; Kökyar socio-economic household survey). Families mostly have two to five members, and both husband and wife are involved in farm work. During harvest time they may hire additional seasonal workers, while in winter some use their spare time to make extra money on Aksu City construction sites. Their main agricultural income is generated by the cultivation of fruit trees and the resulting harvests, with apple and pear being the major crops and jujube, walnut and others being minor crops. As long as fruit trees are still small and do not shade the soil surface, some leasers cultivate maize or cotton between the trees. In addition, many leasers can create indirect incomes from their land: dead wood is used as fencing material or as a fuel substitute for coal; small-scale horticulture and hus- 
Table 5. Averaged annual incomes of and cost to Kökyar I farmers.

\begin{tabular}{|c|c|}
\hline Income and cost item & $\begin{array}{r}\text { Adjusted for } \\
\text { inflation }(2014) \\
\left(\mathrm{CNY} \mathrm{ha}^{-1}\right)\end{array}$ \\
\hline \multicolumn{2}{|l|}{ Gross income } \\
\hline (a) Good harvest (2010) & 86524 \\
\hline (b) Bad harvest (2011) & 42823 \\
\hline (c) Long-term average (acc. Kökyar Annals) & 78704 \\
\hline \multicolumn{2}{|l|}{ Costs } \\
\hline Lease & 8979 \\
\hline Irrigation & 1324 \\
\hline Compulsory labour & 1074 \\
\hline Fertilisers & 11521 \\
\hline Pesticides & 5375 \\
\hline Machines and diesel & 1120 \\
\hline Harvest hands & 3465 \\
\hline \multicolumn{2}{|l|}{ Net income } \\
\hline (a) Good harvest (2010) & 55166 \\
\hline (b) Bad harvest (2011) & 11465 \\
\hline (c) Long-term average (acc. Kökyar Annals) & 47376 \\
\hline
\end{tabular}

bandry beneath the fruit trees contribute to subsistence; animal dung provides some fertiliser. However, only the fruit production is economically significant, and these indirect income items, although they doubtlessly contribute to the living conditions of the farmers, are presently not quantifiable and cannot be incorporated into the subsequent income calculations.

The leasing contracts usually assign areas between 0.5 and 1 ha to the households, with some outliers at 2 or 3 ha, thus fostering small-scale farming. The lease is tailored to the age of the fruit trees and expected yield, shifting between CNY 0 and $15000 \mathrm{ha}^{-1}$. Irrigation water fees usually fall between CNY 1125 and $1275 \mathrm{ha}^{-1}$. (These prices probably represent the costs of the irrigation infrastructure and operation; they do not reflect externalities.) A high share of leasers additionally have to perform compulsory labour of up to 50 man-days per year, its value being assessable by the fees they have to pay if they are unable to carry out the labour. Besides the fixed costs for the lease, irrigation water and compulsory labour, the leasers need to make annual farming investments in fertilisers, pesticides, machinery, diesel and harvest hands. While annual costs are fairly steady, annual incomes vary from year to year, since the yields depend on weather conditions, pests and natural fructification alternations (cf. Table 5). The net income shifts between CNY $55166 \mathrm{ha}^{-1}$ in a good harvest year (2010) and CNY $11465 \mathrm{ha}^{-1}$ in a bad harvest year (2011), with the longterm average being CNY $47376 \mathrm{ha}^{-1}$.

Based on the household survey conducted in 2012, it can be estimated that the household members, on average, have
Table 6. Averaged net incomes per working day of Kökyar I farmers.

\begin{tabular}{lr}
\hline Income situation & $\begin{array}{r}\text { Adjusted for } \\
\text { inflation }(2014) \\
\left.\text { (CNY day }^{-1}\right)\end{array}$ \\
\hline Good harvest (2010) & 306 \\
Bad harvest (2011) & 64 \\
Long-term average (acc. Kökyar Annals) & 263 \\
\hline
\end{tabular}

to work 180 man-days per leased hectare per year (Kökyar socio-economic household survey). Net farming incomes per working day can be calculated by dividing per-hectare net farming incomes by per-hectare work load (cf. Table 6).

While good harvests years appear to provide satisfactory incomes, bad harvest years result in marginal incomes, with the income per man-day lying below the wage level of migrant workers and seasonal workers (Kökyar socio-economic household survey; interview 3). With such strong year-toyear variability, it is hard to evaluate their long-term income situation. However, from the perspective of the farmers themselves, the actual conditions seem to be promising in the long run, since, during the household survey conducted in 2012, nearly all of them were optimistic with regard to the future and declared themselves willing to sign up for the next leasing period (Kökyar socio-economic household survey).

\subsection{The perspective of the governmental organisations}

The state-owned Water Management Station and Forest Management Station as subsidiary bodies of the Aksu River Drainage Area Management Department and the Aksu Prefectural Forestry Department are the organisational backbone of the system. They are responsible for tending the shelterbelts, maintaining roads and canals, operating the irrigation system, managing and enforcing the leasing system, and educating leasers regarding the cultivation of fruit trees. To fulfil these indispensable tasks, they are equipped with all necessary resources and staff, which involves substantial costs (Kökyar Annals Compilation Committee, 1996; Kökyar Annals Compilation Committee, 2006; interview 1). Part of the costs can be covered by lease payments and irrigation water fees derived from the leasing households, yet from the perspective of the government budget, the system is far from economic self-sufficiency (interview 1). As it was not possible to conduct interviews with the persons responsible for the Kökyar project, no exact data on permanent government grants could be gathered. However, an interview with the former head of the Forest Management Station revealed that the Water Management Station and the Forest Management Station can only cover $30 \%$ of their expenses with the income generated from the lease and irrigation water fees. The remaining $70 \%$ of their budget is covered by government grants (interview 1). Lease payments and irri- 
gation water fees can be estimated to be CNY 5.765 million (CNY $8979 \mathrm{ha}^{-1}$ and CNY $1324 \mathrm{ha}^{-1}$ respectively; this is multiplied by 560 ha extant orchard area within Kökyar I (Kökyar socio-economic household survey; Kökyar Annals Compilation Committee, 1996). This being their selfgenerated income share of $30 \%$, the other $70 \%$ covered by governmental grants must amount to CNY 13.451 million, and the total budget must add up to CNY 19.215 million. Unfortunately, it is unknown how the budget is divided between the orchards and the shelterbelts.

In the very near future, the poplar shelterbelts will provide an additional income for the Water and Forest Management Station. Besides their protective value to the orchards, they also have a direct economic value in their timber, which needs to be harvested before becoming overmature. The earliest planted poplars are already almost fit for cutting. As soon as a systematic harvest begins, an annual wood increment of $21.5 \mathrm{~m}^{3} \mathrm{ha}^{-1}$ at a value of CNY $8545 \mathrm{ha}^{-1}$ can be logged in the shelterbelt areas (Kökyar Annals Compilation Committee, 1996; monetary value adjusted for inflation). As investment costs for the shelterbelts are unknown, there is no way to determine the net income they provide. However, a comparison between the expected gross timber income of CNY $8545 \mathrm{ha}^{-1}$ and both the gross and net income of the orchards (CNY 78 704, $47376 \mathrm{ha}^{-1}$; see above) already shows that the shelterbelts are less profitable by far than the orchards.

A timber income of CNY $8545 \mathrm{ha}^{-1}$ translates into an overall timber income of CNY 4785144 for the area of Kökyar I (CNY $8545 \mathrm{ha}^{-1}$, multiplied by 560 ha extant shelterbelts). This additional income reduces necessary annual government grants from 70 to $45 \%$ and, in absolute numbers, from CNY 13.451 million to CNY 8.666 million (values adjusted for inflation). Although a systematic harvest has not yet begun, timber is integrated into the income calculation, since it has regular annual increments which the governmental organisations could convert into income at any time. Incomes and costs of the two stations are summarised in Table 7 .

\subsection{The perspective of the local economy}

The Kökyar Protection Forest originated from the idea of protecting Aksu City against dust and sand storms. However, the invention of the orchard leasing system between the poplar shelterbelts gradually transformed it into a prospering branch of the local economy. The number of leasing households earning their livelihood in the orchards of Kökyar I can be estimated at 324 (Kökyar Annals Compilation Committee, 1996) and 454 (Kökyar socio-economic household survey). Extrapolated to the orchard area of Kökyar I, II and III, these figures would allow an estimated number of 1341 to 1880 farming households. In addition to these, a substantial number of jobs in the background organisation and in
Table 7. Annual incomes of and costs to the Water and Forest Management Station for Kökyar I.

\begin{tabular}{|c|c|}
\hline Income and cost item & $\begin{array}{r}\text { Adjusted for } \\
\text { inflation (2014) } \\
(\text { million CNY) }\end{array}$ \\
\hline \multicolumn{2}{|l|}{ Gross income } \\
\hline Lease income & 5.024 \\
\hline Irrigation water income & 0.740 \\
\hline Timber & 4.785 \\
\hline \multicolumn{2}{|l|}{ Costs } \\
\hline Total costs & 19.215 \\
\hline \multicolumn{2}{|l|}{ Net income } \\
\hline Loss, covered by regular government grants & -8.665 \\
\hline
\end{tabular}

the poplar forests and a smaller number of jobs for suppliers and commercial consumers can be assumed.

However, this whole branch is still dependent on annual government grants for the maintenance, regulation and organisation tasks performed by the Water and Forest Management Station. This section sets out to clarify whether the government grants to Kökyar are justified solely by the protective ecosystem functions it provides or whether it also benefits the local economy.

This question can be answered using cost-benefit analysis by summing up all types of costs and benefits, as they were outlined in the previous sections, and calculating the net benefit. However, prior to this, the figures of the previous sections need to be transformed to fit the needs of the net benefit calculation: firstly, from the perspective of the local economy, it is necessary to account for the time farmers work in their orchards as an additional farming cost, since without the existence of Kökyar, they would contribute to the local economy through other activities. These opportunity costs are calculated at the same daily rate as the compulsory labour they have to perform for their lessors, that is CNY $51.52 \mathrm{day}^{-1}$ (Socio-economic household survey 2012). Given that Kökyar farmers on average invest 180 working days per hectare of orchards (socio-economic household survey), the opportunity costs of farm work can be set at CNY $9289 \mathrm{ha}^{-1}$ (value adjusted for inflation). Secondly, all costs to and incomes of the farming households are given per hectare of orchard land in the previous sections, while costs to the Water and Forest Management Station are only known as a total number, without differentiation into forest types and area sizes. In order to calculate in the same units, per-hectare numbers have to be transformed into total numbers. This is done by multiplying all farming incomes and expenses by 560 ha, the total extant orchard area within the borders of Kökyar I (Kökyar Annals Compilation Committee, 1996). After these preparations, all figures are ready for the net benefit calculation (cf. Table 8). 
Table 8. Annual benefits and costs of Kökyar I from the perspective of local economy.

\begin{tabular}{|c|c|}
\hline Benefit and cost item & $\begin{array}{r}\text { Adjusted for } \\
\text { inflation (2014) } \\
\text { (million CNY) }\end{array}$ \\
\hline \multicolumn{2}{|l|}{ Gross benefits } \\
\hline Fruit harvests (long-term average) & 44.038 \\
\hline Timber & 4.785 \\
\hline Lease income & 5.024 \\
\hline Irrigation water income & 0.741 \\
\hline \multicolumn{2}{|l|}{ Costs } \\
\hline Lease payments & 5.024 \\
\hline Irrigation water fees & 0.741 \\
\hline Compulsory labour & 0.601 \\
\hline Fertilisers & 6.447 \\
\hline Pesticides & 3.008 \\
\hline Machines and diesel & 0.627 \\
\hline Harvest hands & 1.939 \\
\hline Opportunity costs of farm work & 5.198 \\
\hline Expenses of the governmental organisations & 19.215 \\
\hline
\end{tabular}

Net benefit

Annual financial net benefit for the local economy

11.789

The subtraction of all costs from all benefits shows that Kökyar I, in total, generates an overall annual net benefit of CNY 11.789 million. Additionally, it provides regulating ecosystem services of a specific value, which, however, could not be determined in terms of money. The local economy cycle of Kökyar I is graphically represented in Fig. 5.

The overall net benefit of CNY 11.789 million on the total forest area of Kökyar I expressed per area is CNY $10530 \mathrm{ha}^{-1}$. This number, however, applies only to Kökyar I and should not be misunderstood as a general number transferable to Kökyar II, III and IV. While Kökyar I has an orchard share of $50 \%$, Kökyar II and III have greater orchard shares of 58 and $90 \%$, respectively. As mentioned previously, orchards are more profitable by far than shelterbelts; thus Kökyar II and III can be assumed to create considerably greater net benefits to the local economy than Kökyar I.

Thus, it can be concluded that government grants to the Kökyar Protection Forest do not only provide a return in terms of regulating ecosystem services for the citizens of Aksu, but also in terms of financial benefits. From the perspective of the local economy, the Kökyar Protection Forest is self-supporting, more than compensating for necessary annual government grants with respect to the annual farming net benefits. The regulating ecosystem services of wind speed reduction, air filtration and soil fixation, with regard to which the Kökyar Protection Forest was initiated, can therefore be provided to the citizens of Aksu without any payments for ecosystem services (PES) or other additional financial burdens on the local economy.

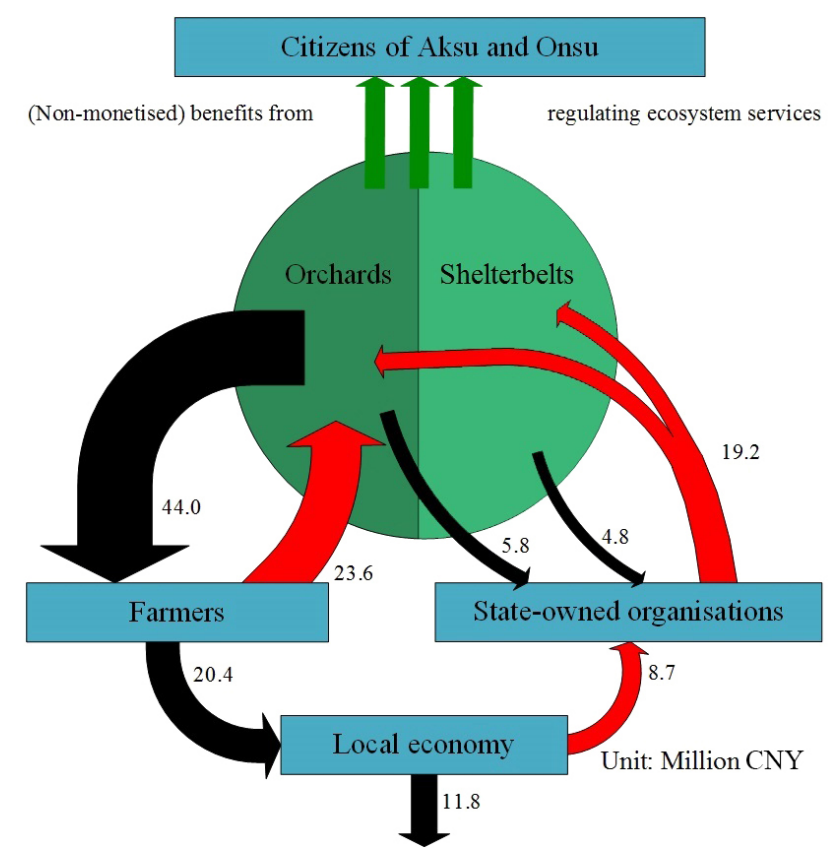

Figure 5. Graphic summary of the cost and benefit flow of Kökyar I (red arrows representing costs, black arrows monetary benefits).

Comparing the initial investment costs of CNY $61245 \mathrm{ha}^{-1}$ with the overall annual net benefit of CNY $10530 \mathrm{ha}^{-1}$ shows that net benefits at the current level would offset initial investment costs within a mere 6 years. However, this is not the actual payback period, since within the first 10 to 15 years after initialisation, fruit trees had not reached full fructification, and consequently there were no or only marginal annual net benefits. The actual historic development of the net benefit has not been researched, but under the simplified assumption of a linear net benefit development from CNY $0 \mathrm{ha}^{-1}$ in the first project year to CNY $10530 \mathrm{ha}^{-1}$ in the 25th project year, the payback period can be approximated to be roughly 20 years. In the case of Kökyar II and III, the payback period can be assumed to be shorter, due to their higher orchard share.

\section{Discussion and outlook}

The paper describes the historic establishment and present functioning of the Kökyar Protection Forest with regard to its institutional frameworks and financial conditions. While the institutional frameworks of Kökyar I and II are described in satisfactory detail, Kökyar III adopts a differing, more market-based approach, which has not been systematically documented yet. Further research could clarify the institutional functioning of Kökyar III, especially in comparison to Kökyar I and II. Concerning the description of the financial conditions, the present financial conditions of Kökyar have formerly not been the subject of any publications; the results of the relevant calculations of this paper, being based on 
a socio-economic household survey comprising 19 leasing households and one additional expert interview with former leading staff of the state-owned organisations, are deemed to be fairly rough estimates. Conducting interviews with actual leaders of the governmental organisations of Kökyar I and II and with large private landholders of Kökyar III would have been extremely desirable; however, under the present political tensions in Xinjiang and with the resulting scepticism towards any type of social surveys, this seems hard to achieve.
For a more comprehensive understanding of the costs and benefits of the Kökyar Protection Forest, future research should be directed towards two main fields. Firstly, the exact physical properties of the regulating ecosystem services provided by the Kökyar Protection Forest still need to be determined, especially regarding the amount of dust and sand avoided in the city of Aksu. Secondly, the negative consequences of the Kökyar water consumption for downstream ecosystems need to be investigated. Principally, every drop of water diverted from Aksu River for the purpose of irrigating the Kökyar Protection Forest is detracted from its lower reaches and its main stem, the Tarim River. The improvement of the quality of life of Han-Chinese settlers in Aksu is thus bought by the resulting desiccation of downstream ecosystems and the consequent loss of downstream ecosystem services, which deprives local Uyghur farmers and herdsmen of their livelihoods. Internalising these downstream effects into the Kökyar water prices may challenge the net benefit and the positive image of Kökyar Protection Forest. 


\section{Appendix A: List of interviews}

Interview 1

- Interviewee: Ibrahim Yusup, head of the Kökyar Greening Project Protection Forest Management Station between 1986 and 1995

- Interviewers: Siegmund Missall, Abdulla Abliz, Aliya Badrulla

- Place and date: Urumqi, 15 October 2012

Interview 2

- Interviewee: Zhang Lei, private farming consultant in Aksu

- Interviewer: Siegmund Missall

- Place and date: Aksu, November 2011

Interview 3

- Interviewee: name unknown, seasonal worker in the orchards of Kökyar Protection Forest

- Interviewers: Siegmund Missall, Abdulla Abliz, Aliya Badrulla

- Place and date: Aksu, January 2012
Aksu citizen interviews

- Interviewees: randomly selected citizens on the streets of Aksu City

- Interviewer: Siegmund Missall

- Place and date: Aksu, November and December 2011

Kökyar socio-economic household survey

- Interviewees: 19 heads of farming households evenly distributed over the area of Kökyar I

- Interviewers: Siegmund Missall, Abdulla Abliz, Aliya Badrulla

- Place and date: Kökyar I, Aksu, January 2012

(The interview series originally focused on the urban green of Aksu, but many interviewees made spontaneous contributions about Kökyar Protection Forest.) 
Acknowledgements. We would like to thank Johannes Küchler for conceptual ideas and scientific guidance, Aliya Badrulla for help during field work, Alex Eden for language correction, Agnieszka Joniak-Lüthi and Madlen Kobi for methodological help in conducting social surveys in Xinjiang, and Mukaram Abdukerim for logistic support.

Edited by: V. Lucarini

\section{References}

Akesu Shi Renmin Zhengfu: Akesu shi qingkuang jianjie, available at: http://www.akss.gov.cn/lsyg/405.jhtml (last access: 14 January 2015), 2012.

Aksu Prefectural Forestry Department and Kuqa Television Station: Lüse zhuangju: jinian Kekeya jianshe 20 nian, Wulumuqi Jitai Keji Youxian Gongsi, Urumqi, 2006.

Aksu Prefectural Greening Committee: Lüse de Kekeya, Hengyuan Zhonghui Caise Baozhuang Youxian Gongsi, Aksu, 2006.

Boardman, A. E., Greenberg, D. H., Vining, A. R., and Weimer, D. L.: Cost-Benefit Analysis: Concepts and Practice, Prentice Hall, New Jersey, 2011.

Chokkalingam, U., Zhou, Z., Wang, C., and Toma, T.: Learning lessons from China's forest rehabilitation efforts, Center for International Forestry Research (CIFOR), Chinese Academy of Forestry Research Institute of Tropical Forestry (RITF), State Forestry Administration Afforestation Department, Jakarta, available at: http://www.cifor.org/publications/pdf_files/Books/ Bchokkalingam0603.pdf (last access: 20 February 2015), 2006.

Delang, C. O. and Yuan, Z.: China's Grain for Green Program: A Review of the Largest Ecological Restoration and Rural Development Program in the World, Springer International Publishing Switzerland, Cham, Heidelberg, New York, Dordrecht, London, 2015.

Halik, Ü.: Stadtbegrünung im ariden Milieu: Das Beispiel der Oasenstädte des südlichen Xinjiang/VR China, Technische Universität Berlin, Berlin, 2003.

Intercontinental Pan-Chinese Network Information Co. Ltd.: Akesu Shi gaikuang, China Xinjiang Web, available at: http://www. chinaxinjiang.cn/xjgk/rkcs/t20080131_320342.htm (last access: 28 April 2013), 2008.

Kökyar Annals Compilation Committee: Kekeya lühua gongcheng zhi, Xinjiang Renmin Chubanshe, Urumqi, 1996.

Kökyar Annals Compilation Committee: Kekeya lühua gongcheng zhi (1996.10-2006.5), Xinjiang Renmin Chubanshe, Urumqi, 2006.
Lang, K. and Li, C.: Linye shengtai gongcheng 10 zhong senlin shengtai xiaoyi jiliang lilun he fangfa, Dongbei Linye Daxue xuebao, 28, 1-7, available at: http://lib.cqvip.com/qk/91092X/ 200001/4085831.html (last access: 28 April 2013), 2000.

Li, M., Liu, A., Zou, C., Xu, W., Shimizu, H., and Wang, K.: An overview of the "Three-North" Shelterbelt project in China, Forest. Stud. China, 14, 70-79, doi:10.1007/s11632-012-0108-3, 2012.

Mishan, E. J. and Quah, E.: Cost-Benefit Analysis, Routledge, Abingdon, New York, 2007.

OECD: Cost-Benefit Analysis and the Environment: Recent Developments - Executive Summary, in Cost-Benefit Analysis and the Environment: Recent Developments, OECD, Paris, 15-27, 2006.

Paproth, F. and Pietsch, C.: Tarim Basin, available at: http://www.sumario.de/image/image_gallery?uuid= 75b70ae9-355b-457e-8466-3e0f577d0c77\&groupId=10544\&t= 1303204620940 (last access: 28 April 2013), 2011.

Qi, H.: "Sanbei” Fanghulin jianshe gongcheng chengguo feiran, Jingji Jishu Xiezuo Xinxi, 945, 8, available at: http://file.lw23. com/3/35/353/35347341-ab42-48fc-9e78-bd04748428b7.pdf (last access: 28 April 2013), 2007.

Rumbaur, C., Thevs, N., Disse, M., Ahlheim, M., Brieden, A., Cyffka, B., Duethmann, D., Feike, T., Frör, O., Gärtner, P., Halik, Ü., Hill, J., Hinnenthal, M., Keilholz, P., Kleinschmit, B., Krysanova, V., Kuba, M., Mader, S., Menz, C., Othmanli, H., Pelz, S., Schroeder, M., Siew, T. F., Stender, V., Stahr, K., Thomas, F. M., Welp, M., Wortmann, M., Zhao, X., Chen, X., Jiang, T., Luo, J., Yimit, H., Yu, R., Zhang, X., and Zhao, C.: Sustainable management of river oases along the Tarim River (SuMaRiO) in Northwest China under conditions of climate change, Earth Syst. Dynam., 6, 83-107, doi:10.5194/esd-6-83-2015, 2015.

Yang, Q. and Cui, C.: The relationship between climate change and surface runoff along the tributaries of the Tarim River, in: Watershed and Floodplain Management along the Tarim River in China's Arid Northwest, edited by: Hoppe, T., Kleinschmit, B., Roberts, B., Thevs, N., and Halik, Ü., Shaker Verlag, Aachen, 247-254, 2006.

Yimit, H., He, L., Halik, W., and Giese, E.: Water resource development and its environmental effects in the Tarim River floodplain, in: Watershed and Floodplain Management along the Tarim River in China's Arid Northwest, edited by: Hoppe, T., Kleinschmit, B., Roberts, B., Thevs, N., and Halik, Ü., Shaker Verlag, Aachen, 91-107, 2006.

Yoshino, M.: Wind and rain in the desert region of Xinjiang, Northwest China, Erdkunde - Archive for scientific geography, 46, 203-216, available at: http://www.jstor.org/discover/10. 2307/25646399? sid=21105342508541\&uid=2\&uid=70\&uid= 2134\&uid=4\&uid=3737864 (last access: 20 February 2015), 1992. 